\title{
Potential of bali cattle: breeding value of bull on weaning weight, yearling weight and body weight
} gain

\begin{abstract}
The performance of Bali cattle in the production of meat has not been maximal. The purpose of the research was to 1). Study potential of Bali bull through breeding value; 2). Analyze of direct and indirect selection response. A total of 1,284 data of weaning weights, yearling weights and body weight gain from 99 cows with 2-7 records were used to analyze the breeding values of bull and selection responses. Estimation of variance and co-variance components of genetic and environmental, and heritability is obtained using the Variance Component Estimation program. PEST program is used to estimate breeding value of bull. Selection response is estimated based on heritability, standard deviation and selection intensity. The results showed that of 28 bulls tested, $53.57 \%$ had a positive breeding value of weaning weight; $42.86 \%$ had a positive breeding value of yearling weight and $53.57 \%$ had a positive breeding value of body weight gain. The direct selection response of weaning weight, yearling weight and body weight gain were $0.26 \mathrm{~kg}, 1.17 \mathrm{~kg}$ and $0.38 \mathrm{~kg}$, respectively, whereas the indirect selection response of weaning weight-yearling weight and weaning weightbody weight gain were $0.21 \mathrm{~kg}$ and $0.04 \mathrm{~kg}$ respectively.
\end{abstract}

Keywords: bali cattle, breeding value, selection responses
Volume 3 Issue 5 - 2018

\author{
Andoyo Supriyantono,' Widayat ITW,' \\ Sumpe I,' Sritiasni ${ }^{2}$ \\ 'Department of Animal Science, Papua University, Indonesia \\ ${ }^{2}$ Department of Animal Science,Agricultural Extension College, \\ Indonesia
}

Correspondence: Andoyo Supriyantono, Department of Animal Science, Papua University, Indonesia, Email andoyo@yahoo.com

Received: August 01, 2018 | Published: October 03, 2018

\section{Introduction}

The demand for meat in Indonesia increases by $6-8 \%$ each year, especially in densely populated areas such as Java. The increase is in line with the increasing population, income level and public awareness of the importance of nutrition from livestock.

Fulfillment of domestic meat is partly supplied by local beef cattle like Bali, Ongole, Madura and some other beef cattle breed. According to Indonesian livestock statistics, Bali cattle population occupies the highest number (26.92 percent), it means that the contribution of Bali cattle to meet the meat needs is very important. Nevertheless, the performance of Bali cattle in the production of meat has not been maximal so it needs various efforts to optimize it. Current and ongoing efforts in some areas include the adoption of various feeding strategies, ${ }^{1,2}$ raising management ${ }^{3,4}$ and genetic improvement through selection. ${ }^{5,6}$

Growth performance of Bali cattle has been a major concern, especially in body weight gain, birth weight and weaning weight. In addition to growth performance, reproductive traits such as service per conception, calving rate, calving intervals and fertility are as successfully parameters of mating program in artificial insemination. Some research results in Bali cattle show that service per conception is $1.8-2.00^{1}$ and calving rate $64-78 \%{ }^{4}$ The body weight gain with good feed can reach $0.7 \mathrm{~kg} /$ day (adult male) and $0.6 \mathrm{~kg} / \mathrm{day}$ (adult female), carcass percentage $51.5-59.8 \%$, with bone percentage less than 15 percent and low-fat meat. ${ }^{7}$

Those potentials encourage Indonesian government to conserve and develop the genetic resources of Bali cattle by establishing BPTU (Bali Cattle Breeding Center). Breeding center of Bali cattle has specific activity including includes breeding, propagation, disease control, distribution, quality control, livestock resources preservation and environmental control.

Selection can be performed on males and females on economically valuable traits such as weaning weight, yearling weight and body weight gain. Selection of these traits has been largely done in beef cattle in some countries, ${ }^{8-11}$ while in Bali cattle still rarely done. ${ }^{12-14}$ The purpose of this study is to 1). Study potential of Bali bull through breeding value; 2). Analyze of direct and indirect selection response.

\section{Material and methods}

A total of 1,284 Bali cattle data from Balai Pemulitan Ternak Unggul (BALI Cattle Breeding Center) was used to analyze the breeding value of males and selection response. The data consisted of weaning weights, yearling weights and body weight gain with the same number for each trait (428 data per trait). The data was from 99 cow with 2-7 records per cow.

Estimation of variance and co-variance components of genetic and environmental, and heritability is obtained using the variance component estimation program 4.2. ${ }^{15}$ Fixed effects are precipitation, age of measurement and year of birth whereas as a random effect is animals.

In general the statistical model for animal models is: $\mathrm{Yi}=\mathrm{Xibi}$ + Ziui + ei. Where: $\mathrm{Y}=$ observation vector: $\mathrm{n} \times 1 ; \mathrm{b}=$ vector of $\mathrm{a}$ fixed effect: $\mathrm{p}$ x $1 ; \mathrm{u}=$ vector of a random effect: $\mathrm{q} \times 1$ having a matrix of variance covariance of $\mathrm{G}$ which is a vector of evaluated breeding values; $\mathrm{X}=$ known matrix expressing a fixed effect (b); $\mathrm{Z}=$ known matrix expressing a random effect $(\mathrm{u}) ; \mathrm{e}=$ an unobservable of random vector: $\mathrm{n} \times 1$ with a matrix of variance covariance of $\mathrm{R} .{ }^{16}$

Selection response is estimated based on heritability value 
obtained, standard deviation of population and selection intensity (i). The intensity of selection determines the magnitude of the selection response achieved by each generation, the fewer animal selected to be parental to produce progeny of next generations, the higher selection intensity. The value of selection intensity was obtained by Table. ${ }^{17}$

The Estimation of breeding values (BV) is performed on bull for weaning weights, yearling weight and body weight gain. The BV of each character are estimated using the PEST program ${ }^{18}$ by inserting of genetic variant values ( $\mathrm{vg}$ ) and environments variance (ve) of the same trait. Those values are obtained from the output of the VCE 4.2 program.

Falconer et al., ${ }^{17}$ Warwick et al., ${ }^{19}$ Hardjosubroto et al. ${ }^{20}$ formulated estimations of the direct and indirect selection response as follows:

Direct selection: $\mathrm{R}_{\mathrm{s}}=\frac{i \sigma_{P} h^{2}}{l}$;

Indirect selection: $\mathrm{CR}_{\mathrm{y} 2.1}=\frac{i h_{1} h_{2} r_{g} \sigma_{p 2}}{l}$

Where: Rs = direct selection response; $\sigma \mathrm{p}=$ standard deviation; $\mathrm{h}^{2}$ $=$ heritability; CRy2.1 $=$ indirect selection response; $\mathrm{h}_{1}=$ square root of heritability of first trait; $h_{2}=$ square root of heritability of second trait; $\mathrm{rg}=$ genetic correlation of first and second character; $\sigma \mathrm{p} 2=$ standard second character deviation; $\mathrm{i}=$ average intensity of selection; $1=$ average generation interval

\section{Results and discussion}

The best ten bulls based on breeding value of weaning weight, yearling weight and body weight gain are presented in Table 1, which can be summarized as in Figure 1-3.

Noted: BV, breeding value; Bulls code, one and two digits are AI; others are natural mating.

Table I The best ten bulls based on breeding value of weaning weight, yearling weight and body weight gain

\begin{tabular}{|c|c|c|c|c|c|c|}
\hline \multicolumn{2}{|c|}{ Weaning weight } & \multicolumn{2}{|c|}{ Yearling weight } & \multicolumn{2}{|c|}{ Body weight gain } & \multirow{2}{*}{ Rank } \\
\hline $\begin{array}{l}\text { Bulls } \\
\text { code }\end{array}$ & BV & $\begin{array}{l}\text { Bulls } \\
\text { code }\end{array}$ & BV & $\begin{array}{l}\text { Bulls } \\
\text { code }\end{array}$ & BV & \\
\hline 73996 & 12.164 & 4 & 20.748 & 4 & $|0.75|$ & I \\
\hline I & 8.564 & 79792 & 15.68 & 77789 & 8.476 & 2 \\
\hline 79792 & 8.151 & I & 9.874 & 75994 & 6.659 & 3 \\
\hline 105293 & 7.517 & 75994 & 9.793 & 79792 & 6.303 & 4 \\
\hline II & 7.242 & 105293 & 9.583 & 3 & 5.436 & 5 \\
\hline 74591 & 5.085 & 3 & 9.461 & 6 & 3.568 & 6 \\
\hline 5 & 4.725 & 77789 & 8.905 & 73091 & 2.908 & 7 \\
\hline 77789 & 4.649 & 73491 & 8.439 & I & 2.672 & 8 \\
\hline 8 & 4.073 & 309293 & 3.813 & 309293 & 2.395 & 9 \\
\hline I 10296 & 3.519 & 10 & 2.51 & 10 & 2.288 & 10 \\
\hline
\end{tabular}

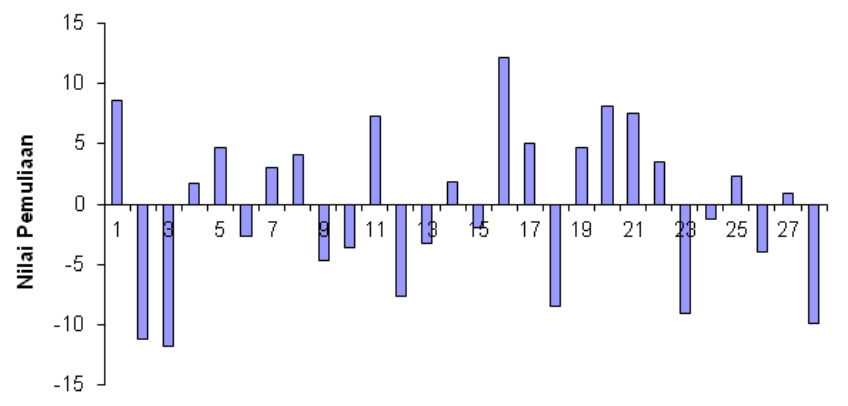

Kode Pejantan

Figure I Breeding value of weaning weight.

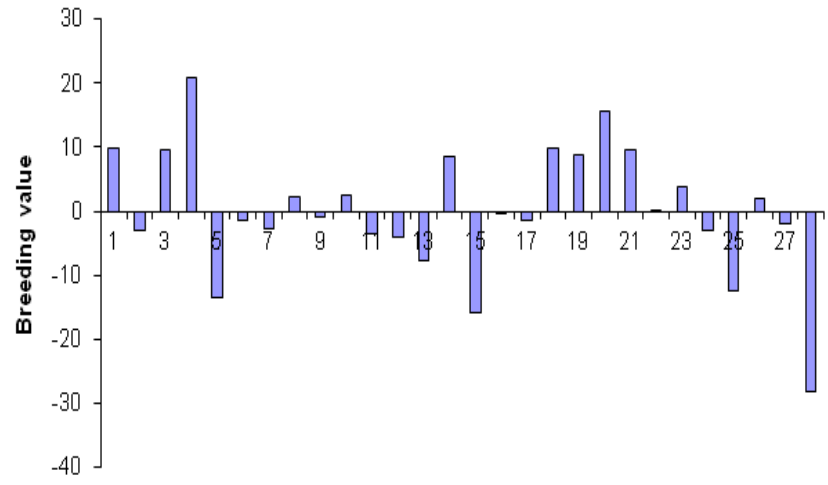

Bulls code

Figure 2 Breeding value of yearling weight.

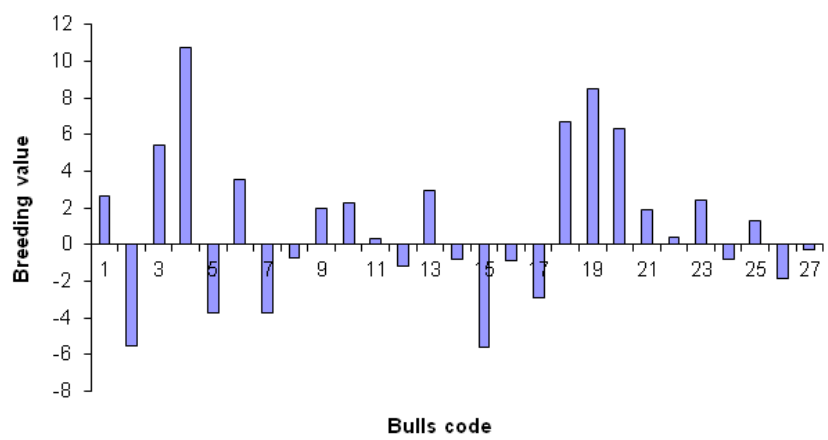

Figure 3 Breeding value of body weight gain.

The best ten of bulls based on weaning weights, yearling weights, and body weights gain are different in order each other. Of weaning weight and yearling weight, natural bulls are more than AI bulls whereas of body weight gain, the numbers are balanced between AI and natural bulls.

Figure 1 shows that of the 28 bulls tested, 53.57 percent of them have a positive breeding value of weaning weight. Of the 28 males tested, 11 were bulls from frozen semen center (BBIB Singosari) however it was only 54.54 percent ( 6 bulls) had a positive breeding value of weaning weight.

For yearling weight, of 28 males tested 42.86 percent had a positive breeding value. However only 18.18 percent ( 2 bulls) of 11 
bulls come from frozen semen center (BBIB Singosari) had a positive breeding value of yearling weight.

Breeding value of body weight gain from bulls tested, 53.57 percent had a positive breeding value, 46.67 percent of them were from frozen semen center (BBIB Singosari). The higher breeding value of bulls indicated the superiority of them compared to others, since the bulls with high BV will have offspring relatively advantages as well. Therefore, BV can be used as one of the selection criteria for selecting superior bulls for the widest use of semen in the project area or elsewhere.

Based on BV of weaning weights, yearling weights and body weight gain it can be concluded that the order of ten best bulls were difference between traits. The difference in the order of the bulls was caused of not all animals have a complete record. The animals which have weaning weight data on 2003 did not have yearling weight record. BLUP with VCE program allows to analyze of data with such conditions. Another cause is the negative body weight gain on some animals, which affects the mean of population. When the economic value for each trait is known then we can find the cumulative breeding value of the traits. In this study we did not know economic values for each trait so that it cannot be used as weighting to rank bulls based on all traits.

The least of AI bulls in the top ten indicated that the natural bulls used is well adapted to the tropical environment so they are able to express their genetic capability as well. Although it is known that the AI bulls has high genetic quality however from the breeding value estimation the natural bulls were better bulls.

The highest breeding value of weaning weight is the bull coded 73996 with a relative breeding value of 12.164 , it means that if the bull 73996 mated to the cows randomly then the mean weaning weight of offspring will be 6.08 higher than the mean weaning weight of population, because bulls superiority will be transferred by a half of breeding value. ${ }^{20}$

A male when used as a live bull naturally has limitations due to age. Furthermore, when the age considered as point of viewed, all males who fall into the top ten were old. The utilization of live bulls in the top ten should be considered due to the limitation of age. Those bulls should be used for the producing semen in BBIB Singosari as semen center.

To estimate direct selection response of some traits, we used selection intensity based on the number of animals who have breeding values above the average for each selected traits, as presented in Table 2

Noted: I, selection intensity; $\mathrm{h}^{2}$, heritability

Table 2 Direct selection response (Rs) some traits

\begin{tabular}{llllll}
\hline Traits & $\mathbf{i}$ & $\mathbf{h}^{2}$ & SD & $\begin{array}{l}\text { Rs/ } \\
\text { generation }\end{array}$ & Rs/year \\
\hline Weaning weight & $\mathrm{I}, 30$ & 0,09 & $\mathrm{II}, 79$ & $\mathrm{I}, 38$ & 0,26 \\
Yearling weight & $\mathrm{I}, 35$ & 0,27 & $\mathrm{I}, 32$ & 6,31 & $\mathrm{I}, 17$ \\
Body weight gain & 0,88 & 0,47 & 4,98 & 2,06 & 0,38 \\
\hline
\end{tabular}

To estimate the direct selection response per year, it is necessary to calculate generation interval of Bali cattle population in Pulukan. Of the population of Bali cattle in BPTU the generation interval is calculated based on the age distribution of the bulls and cow used. Generation interval for cow was 6.5 years and for bulls was 4.3 years old and the average was 5.4 year.

Indirect selection response between weaning weight and some other traits is presented in Table 3. The calculation of pair's traits was due to weaning weight earlier coming than other traits measured, it can be more efficient when selection is done for weaning weight. We also put direct selection response in the last column of Table 3 as a comparison to indirect selection response.

Table 3 Indirect selection response between weaning weight and other traits

\begin{tabular}{lllllllll}
\hline Traits & rg & h1 & h2 & SD2 & i & I & CRy2.I & Rind \\
\hline $\begin{array}{l}\text { WW } \\
\text { vs }\end{array}$ & 0.314 & 0.3 & 0.52 & 17.32 & 1.33 & 5.4 & 0.21 & 1.17 \\
YW & & & & & & & & \\
$\begin{array}{l}\text { WW } \\
\text { vs } \\
\text { BWG }\end{array}$ & 0.182 & 0.3 & 0.69 & 4.98 & 1.09 & 5.4 & 0.04 & 0.38 \\
\hline
\end{tabular}

Noted: WW= weaning weight; YW, yearling weight; BWG, body weight gain; $h_{1}$, square root of $h^{2}$ of $W W ; h_{2}$, square root of $h^{2}$ of YW or BWG; $\mathrm{SD}_{2}$, standard deviation of YW or BWG; I, selection intensity; 1 , generation interval; $\mathrm{CR}$, correlateed response; $\mathrm{R}_{\text {ind }}$, direct selection.

As it is known that the average generation interval in Pulukan was 5.4 years, with reference to the optimum selection response it will get an annual selection response of $0.37 \mathrm{~kg}$. Currently average of weaning weight is equal to $82.09 \mathrm{~kg}$ then ten years to come average weaning weight will be of $85.79 \mathrm{~kg}$. This figure is still far from the initial goal that in 12 years since the establishment of the project is expected reached $120-130 \mathrm{~kg}$.

Factors that become obstacles in achieving of weaning weight are (1) improper in selection for candidates of performance test. It was only based on body weight of $140 \mathrm{~kg}$ without considering genetic quality. For performance test the project need 50 male as a participant. The need of participants was not entirely fulfilled from Pulukan or Tabanan. Lack of participants was obtained through purchases from the Bringkit animal market, which makes one of the weaknesses in achieving the target. The decrease in the number of participants of the performance test was more due to the fact that in 1988 there was an outbreak of Jembrana disease which resulted in most of the cows in Pulukan dead. To reduce this risk, the number of participants was reduced from the original 100 animals to 50 animals; (2). The decrease in the number of participants of performance test resulted in the decrease in the number of males who participated in the progeny testing so that the selection for males became very limited. This situation was exacerbated by declining credit facilities in Tabanan which resulted in the number of cow were also reduced. The impact of this reduced number of cow was the loss of at least $50 \%$ chance of genetic progress as targeted..$^{21}$ (3) Utilization of a larger progeny testing than initially set (only 5 percent). This was because the extent of the spread of the cow at the farmer level and the lack of AI facilities for progeny testing leads to the need for large numbers of males as natural mating; (4) loss of the cow with superior performance at the end of the five-year credit period, because automatically the lender participant will end the status of the participant when it has paid the payment for five years.

In Pulukan, the need of beef seeds could not be fulfilled from the population itself. The data indicated that the number of cattle decreases with the percentage of death greater than the percentage 
of birth that was -5.81 percent. The low percentage of births was due to the number of effective cow that is present in the population was also low by 24.66 percent. In the ideal population the number of effective cow should reach $45-60$ percent, ${ }^{20}$ allowing the seedlings to be fulfilled from the population itself. Although the percentage of calf harvest reaches 61.18 percent, but due to uneven proportion of cow age, the percentage of calf harvest is not able to meet the needs of the seed itself.

When the optimum age of females is considered in breeding, older females aged above seven years should be excluded from the population. According to ${ }^{22}$ that maintaining livestock to old age will extend the generation interval resulting in a decrease of the selection response, but the estimate of breeding value will be more accurate. On the other hand, shortening the generation interval will improve the selection response but the accuracy of the breeding value will decrease.

\section{Conclusion}

From the results and discussion can be concluded that:

The best ten based on weaning weights, yearling weights and body weight gain are different from each other, with more natural mating males than AI males.

Of the 28 males tested, $53.57 \%$ had a positive breeding value of weaning weight including 6 bulls from BBIB Singosari (semen center); on yearling weight traits, $42.86 \%$ of bulls had positive breeding value with 2 males of BBIB Singosari; breeding value of body weight gain from tested bulls, 53.57 percent had positive breeding value, 46.67 of which were AI bulls.

Direct selection response of weaning weight, yearling weight and body weight gain was $0.26 \mathrm{~kg}, 1.17 \mathrm{~kg}$ and $0.38 \mathrm{~kg}$, respectively. Whereas the correlated (indirect) selection response between weaning weight-yearling weight and weaning weight- body weight gain was $0.21 \mathrm{~kg}$ and $0.04 \mathrm{~kg}$ respectively.

\section{Acknowledgements}

None.

\section{Conflict of interest}

The author declares there are no conflicts of interests.

\section{References}

1. Mastika IM. Feeding Strategies to Improve the Production Performance and Meat Quality of Bali Cattle (Bos sondaicus). Australian Centre for International Agricultural Research: Canberra. 2003.

2. Pengelly BC, Dan SN Lisson. Strategies for Using Improved Forages to Enhance Production in Bali Cattle. Working Papers: Bali Cattle Workshop.2002.

3. Oka L. Performance of Bali Heifers and Calves prior to Weaning in Feedlot System. 2005.

4. Bamualim A. Wirdahayati RB. Nutrition and Management Strategies to Improve Bali Cattle Productivity in Nusa Tenggara. 2003.

5. Graser H. Strategies to Improve Bali Cattle in Eastern Indonesia: Implementing Pedigree System. Bali Cattle Workshop. Bali. 2002.

6. Toelihere MR. Increasing the Success Rate and Adoption of Artificial Insemination for Genetic Improvement of Bali Cattle. Bali Cattle Workshop. 2002.

7. Pane I. Produktivitas dan Breeding Sapi Bali. Proceeding Seminar Nasional Sapi Bali. 1991:50-69.

8. Koch RM, Cundiff LV, Gregory KE, et al. Genetic response to selection for weaning weight or yearling weight or yearling weight and muscle score in Hereford cattle: Efficiency of gain, growth, and carcass characteristics. J Anim Sci. 2004;82(3):668-682.

9. Bennett GL. Experimental selection for calving ease and postnatal growth in seven cattle populations. I. Changes in estimated breeding values. J Anim Sci. 2008;86(9):2093-2102.

10. Bennett GL, Thallman RM, Snelling WM, et al. Experimental selection for calving ease and postnatal growth in seven cattle populations. II. Phenotypic differences. J Anim Sci. 2008;86(9):2103-2114.

11. Boligon AA, Vicente IS, Vaz RZ, et al. Principal component analysis of breeding values for growth and reproductive traits and genetic association with adult size in beef cattle. J Anim Sci. 2016;94(12):50145022 .

12. Jan R. Penampilan Sapi Bali di Wilayah Proyek Pembibitan dan Pengembangan Sapi Bali di Daerah Tingkat I Bali.2000.

13. Sukmasari AH, RR Noor, H Martojo, et al. Pendugaan Nilai Pemuliaan dan Kecenderungan Genetika Bobot Badan Sapi Bali di Proyek Pembibitan dan Pengembangan Sapi Bali. 2002;9(4):109-113.

14. Supriyantono A, Hakim L, Suyadi, et al. Breeding Programme Development of Bali Cattle at Bali Breeding Centre. Journal of Animal Production.2011;13(1): 45-51.

15. Groeneveld E. VCE4 Programme, User's Guide and Manual Version 1.1. Institut furr Tierzuch und Tierverhalten. FAL: Mariensee; 1998.

16. Henderson CR. Best Linear Unbiased Prediction of Nonadditive Genetic Merits in Noninbred Populations. J of Animal Sci.1985;60(1):111-117.

17. Falconer DS, Mackay TFC. Introduction to Quantitative Genetics. $4^{\text {th }}$ Edition. Addison Wesley Longman Limited. Edinburgh Gate, Harlow. 1996.

18. Groeneveld E. PEST User's Manual. FAL, Nuestadt.1990.

19. Warwick EJ, JM Astuti Dan W Hardjosubroto. Pemuliaan Ternak. Gadjah Mada University Press, Yogyakarta.1990.

20. Hardjosubroto W, Aplikasi Pemuliabiakan, Ternak di Lapangan. PT. Gramedia Widiasarana Indonesia, Jakarta.1994.

21. Van Asch RG, Morris G, McEvoy M, et al. Draft Final Report: Review of the Bali Cattle Breeding and Development Project. The New Zealand Ministry of External Relations and Trade. New Zealand.1990.

22. Van Der Werf J. Livestock straight-breeding system structures for the sustainable intensification of extensive grazing system. In: Galal S, J Boyazoglu, K Hammond, editors. Workshop on developing breeeding strategies for lower input animal production environments. 1999;105177. 